\author{
Wahyuni Yasmin ${ }^{1}$ \\ Mufarizuddin $^{2}$ \\ Ramdhan Witarsa ${ }^{3}$
}

\section{KAJIAN LITERATUR KETERAMPILAN BERBICARA DENGAN MENGGUNAKAN MODEL EXPLICIT INSTRUCTION PESERTA DIDIK DISEKOLAH DASAR}

\begin{abstract}
Abstrak
Skripsi ini adalah hasil penelitian studi pustaka (library research) yang berjudul " kajian literatur keterampilan berbicara dengan menggunakan model explicit instruction peserta didik disekolah dasar". Penelitian ini bertujuan untuk mendeskripsikan literatur tentang keterampilan berbicara dengan menggunakan model explicit instruction peserta didik disekolah dasar. Metode penelitian ini adalah metode penelitian kajian litaratur yang mengkaji keterampilan berbicara dengan menggunakan model explicit instruction. Penelitian ini didasari dengan sulitnya mencari data lapangan dikerenakan sekolah yang tutup karena pandemi covid 19 yang melanda kita semua. Subjek penelitian ini adalah 15 artikel yang diterbitkan dijurnal nasional dalam waktu 5 tahun terakhir. Artikel keterampilan berbicara terdiri dari 7 artikel, model explicit instruction terdiri dari 8 artikel. Dari hasil kajian literatur diperoleh 46,6\% merupakan keterampilan berbicara. Kemudian 53,5\% merupakan model explicit instruction. Kebaruan penelitian yang didapat secara kajian literatur tentang keterampilan berbicara dan model explicit instruction sesuai dengan teori-teori yang disampaikan ahli-ahli sebelumnya. Dampak dan impak hasil penelitian menggunakan kajian literatur ini adalah bagi peneliti lainnya apabila ingin meneliti tentang keterampilan berbicara dan model explicit instruction bisa memperhatikan saran-saran yang telah diberikan peneliti.
\end{abstract}

Kata Kunci: Keterampilan Berbicara, Model Explicit Instruction.

\begin{abstract}
This research was carried uot based on the problem of speaking skills by using explicit instruction model of student in elementary school. This script is aresult of library research entitled "literature review speaking skills by using explicit instruction model of student in elementary school". This research was aimed to determine literature about speaking skills by using explicit instruction model in elementary school. The method of this research was. Literature review which is axamined speaking skills by using explicit instruction model. This research was based on difficulty to pinding field data, because of the pandemic covid-19 the school was closed. The subject of this research consist of

\footnotetext{
${ }^{1}$ Pendidikan Guru Sekolah Dasar, Fakultas Ilmu Pendidikan, Universitas Pahlawan Tuanku Tambusai Alamat email wahyuniyasmin@gmail.com
} 
15 articles, published by National Journal in 5 years latest. There are 7 articles of speaking skills and 8 articles about explicit instruction model. The result showed that $46,6 \%$ speaking skills then 53,5\% was explicit instruction model. The research update about speaking skills by using explicit instruction model based on the theoris delivered by experts before. The effect and impact this research outcame literature review to the other research who wunbs to investigate about speaking skills by using explicit instruction model instruction model that should notice the suggestion to research delivered.

\section{Keywords : Speaking Skills, Explicit Instruction Model}

\section{PENDAHULUAN}

Penelitian ini difokuskan pada masalah kemampuan berbicara peserta didik kelas III yang masih sangat rendah sehingga mempengaruhi kelancaran proses pembelajaran di kelas. Sebagaimana diketahui bahasa Indonesia adalah sarana komunikasi yang dapat digunakan dalam proses pembelajaran, memiliki peran penting bagi guru dan peserta didik dalam menyampaikan maksud dan gagasannya kepada orang lain.

Hal ini merupakan bentuk keterampilan berbahasa yang meliputi empat keterampilan dasar tadi, yaitu menyimak, berbicara, membaca, dan menulis. Sebagai institusi pendidikan formal, Sekolah Dasar memiliki fungsi dan peran strategis dalam melahirkan generasi-generasi masa depan yang terampil berbahasa Indonesia secara baik dan benar. Dengan memiliki keterampilan berbahasa Indonesia secara baik dan benar, kelak mereka diharapkan menjadi generasi yang cerdas, kritis, kreatif, dan berbudaya. Keterampilan berbahasa yang penting peranannya dalam melahirkan generasi masa yang cerdas dan kreatif adalah keterampilan berbicara. Kemampuan berbicara dengan baik, siswa akan bisa menyalurkan ide-ide dan perasaannya secara cerdas sesuai konteks dan situasi pada saat dia sedang berbicara. Keterampilan berbicara juga akan mampu membentuk generasi masa depan yang kreatif sehingga mampu melahirkan tuturan atau ujaran yang komunikatif, jelas, runtut, dan mudah dipahami.

Keterampilan berbicara juga akan mampu melahirkan generasi masa depan yang kritis karena mereka memiliki kemampuan untuk mengekspresikan gagasan, pikiran, atau perasaan kepada orang lain secara runtut dan sistematis. Bahkan, keterampilan berbicara juga akan mampu melahirkan generasi masa depan yang berbudaya karena sudah terbiasa berkomunikasi dengan lingkungannya sesuai dengan konteks dan situasi tutur saat sedang berbicara. Keterampilan berbicara peserta didik belum mencapai hasil sesuai yang diharapkan.

Kondisi ini tidak lepas dari proses pembelajaran bahasa Indonesia di sekolah yang menjadi tugas semua pihak sekolah, terutama guru bahasa Indonesia. Peran guru sangat penting dalam membantu siswa untuk terampil berbicara ( Witarsa, 2015). Hasil wawancara menunjukkan hanya $2-5 \%$ peserta didik yang dinilai sudah terampil berbicara dalam situasi formal di kelas. Indikator yang digunakan untuk mengukur keterampilan peserta didik dalam berbicara ada lima aspek yakni (1) kelancaran berbicara, (2) ketepatan pilihan kata (diksi), (3) struktur kalimat, (4) kelogisan (penalaran), dan (5) komunikatif/kontak mata. Sesuai berbagai sumber menyebutkan ada dua faktor yang menyebabkan rendahnya tingkat keterampilan siswa dalam berbicara, yaitu faktor eksternal dan internal. Yang termasuk faktor eksternal, yaitu pengaruh penggunaan bahasa Indonesia dalam keluarga dan lingkungan. Dalam proses komunikasi sehari-hari, banyak keluarga yang menggunakan bahasa ibu (bahasa daerah) sebagai bahasa percakapan dalam keluarga.

Penggunaan bahasa Indonesia dilingkungan, Bahasa ibulah yang digunakan sebagai sarana komunikasi. Sehingga kadangkala bahasa Indonesia yang digunakan belum memperhatikan kaidah berbahasa yang baik dan benar. Inilah yang menyebabkan siswa tidak terbiasa untuk berbahasa Indonesia sesuai dengan aturan kebahasaan yang baku. Faktor internal terjadi pada situasi pendekatan pembelajaran, metode, media, atau sumber pembelajaran yang digunakan oleh guru memiliki pengaruh yang cukup signifikan terhadap tingkat keterampilan berbicara 
terutama bagi peserta didik di SD. Guru bahasa Indonesia cenderung menggunakan pendekatan yang konvensional dan tidak inovatif sehingga pembelajaran keterampilan berbicara tidak berlangsung secara kondusif.

Kelemahan lain yang kadang kala dilakukan oleh guru adalah siswa tidak diajak untuk belajar berbahasa, tetapi cenderung diajak belajar tentang tata bahasa. Artinya, apa yang disajikan oleh guru di kelas bukan mengarahkan siswa untuk pandai berbicara, melainkan diajak untuk mempelajari teori tentang berbahasa. Akibatnya, keterampilan berbicara hanya sekadar melekat pada diri siswa secara rasional dan kognitif semata, belum terintegrasi secara emosional dan afektif. Rendahnya keterampilan berbicara bisa menjadi hambatan bagi siswa untuk menjadi siswa yang cerdas dan kreatif.

Beberapa penelitian ditemukan bahwa pengajaran bahasa Indonesia telah menyimpang jauh dari misi sebenarnya. Guru lebih banyak berbicara tentang bahasa daripada melatih peserta didik berbicara. Dengan kata lain, yang ditekankan adalah penguasaan tentang bahasa. Jika kondisi pembelajaran semacam itu dibiarkan berlarut-larut, maka keterampilan berbicara di kalangan peserta didik SD akan terus menurun. Para peserta didik akan mengalami kesulitan dalam mengekspresikan pikiran dan perasaannya secara lancar, mereka tidak mampu memilih kata (diksi) yang tepat dalam berbicara, mereka tidak bisa menyusun struktur kalimat yang efektif, tidak mampu membangun pola penalaran yang masuk akal, dan menjalin kontak mata dengan pihak lain secara komunikatif dan interaktif pada saat berbicara. Dalam konteks demikian, diperlukan pendekatan pembelajaran keterampilan berbicara yang inovatif dan kreatif dengan memadukan metode latihan di dalamnya, sehingga proses pembelajaran bisa berlangsung aktif, efektif, dinamis, dan menyenangkan. Peserta didik tidak hanya diajak untuk belajar tentang tata bahasa, tetapi juga diajak untuk belajar dan berlatih dalam berbicara.

Pembelajaran keterampilan berbicara pun menjadi materi pembelajaran yang menyenangkan. Dalam penelitian ini, model pembelajaran yang digunakan adalah yang dapat merangsang peserta didik untuk berpartisipasi ( Mufatizuddin, 2017). Salah satu model yang dapat digunakan untuk meningkatkan hasil belajar adalah model pembelajaran Explicit Instuction. Explicit Instruction merupakan suatu pendekatan yang dirancang untuk mengembangkan belajar peserta didik tentang pengetahuan prosedur dan pengetahuan deklaratif yang dapat diajarkan dengan pola selangkah demi selangkah, Suyatno (2009:127).

Berdasarkan kajian literatur, dapat disimpulkan bahwa model Explicit Instruction merupakan model pembelajaran yang melibatkan siswa. Berdasarkan uraian di atas, peneliti tertarik untuk melakukan penelitian ini dengan judul : "Kajian Literatur Kemampuan Berbicara Dengan Menggunakan Model Explicit Instruction Peserta Didik Di Sekolah Dasar"

\section{METODE}

Metode penelitian ini adalah metode penelitian kajian litaratur yang mengkaji keterampilan berbicara dengan menggunakan model explicit instruction. . Penelitian ini didasari dengan sulitnya mencari data lapangan dikerenakan sekolah yang tutup karena pandemi covid 19 yang melanda kita semua. Penelitian ini bertujuan untuk mendeskripsikan literatur tentang keterampilan berbicara dengan menggunakan model explicit instruction peserta didik disekolah dasar. Metode penelitian ini adalah metode penelitian kajian litaratur yang mengkaji keterampilan berbicara dengan menggunakan model explicit instruction. Penelitian ini didasari dengan sulitnya mencari data lapangan dikerenakan sekolah yang tutup karena pandemi covid 19 yang melanda kita semua. Subjek penelitian ini adalah 15 artikel yang diterbitkan dijurnal nasional dalam waktu 5 tahun terakhir. Artikel keterampilan berbicara terdiri dari 7 artikel, model explicit instruction terdiri dari 8 artikel.

\section{HASIL DAN PEMBAHASAN}


Hasil penelitian dari 15 artikel yang dipilih sesuai dengan keterampilan berbicara dengan menggunakan model explicit instruction yaitu sebagai berikut: 1. Pengembangan Media Pembejaran Boneka Kaus Kaki Untuk Meningkatkan Keterampilan Berbicara Siswa Kelas II Sekolah Dasar, Erwin Putera Permana. 2. Efektivitas Penggunaan Model Pembelajaran Role Playing Terhadap Ketrampilan Berbicara Pada Bahasa Indonesia Tingkat SD, Rika Kurnia Sari. 3. Meningkatkan Keterampilan Berbicara Siswa Menggunakan Model Time Token Pembelajaran IPA Kelas V Sekolah Dasar, Rafika Siregar, Atri Widowati, Muhammad Ali. 4. Peningkatan Keterampilan Berbicara Menggunakan Metode Kooperatif Tipe Jigsaw Pada Mahasiswa Pbsi Tingkat I-B Ikip Pgri Bojonegoro, Agus Darmuki,Ahmad Hariyadi. 5. Peningkatan Keterampilan Berbicara Melalui Model Pembelajaran Kooperatif Tipe Artikulsi Pada Siswa Kelas VI SD Inpres 3 Talise, Vitta Kariani. 6. Metode Bermain Peran Dalam Penerapan Keterampilan Berbicara Pada Siswa Kelas 5 Sekolah Dasar, Irna Siskatrin Suhaylide. 7. Penerapan Pendekatan Saintifik Berbantuan Media poster Dapat Meningkatkan Keterampilan berbicara Dalam Bahasa Indonesia Tema Cita-Cita, Ni Kd Wijayant, M.G. Rini Kristiantari , I.B. Surya Manuaba.8. Penerapan Model Pembelajaran Explicit Instruction Untuk Meningkatkan Hasil Belajar Siswa Pokok Bahasan Cahaya Dan Sifatnya Pada Siswa Kelas V Di SD Negeri 1 Sembawa, Agus Saeful Anwar, Peti Lapenia. 9. Pengaruh Model Pembelajaran Explicit Instruction Berbantuan Lingkungan Alam Sekitar Terhadap Hasil Belajar Ipa Siswa Kelas IV, Rahmawati Utari Desak Putu Parmiti , Dewa Nyoman Sudana. 10. Penerapan Model Pembelajaran Kooperatif Tipe Explicit Instruction Dalam Meningkatkan Hasil Belajar IPS Pada Siswa Kelas IX SMP Negeri 2 Bontoramba Kabupaten Jeneponto Ridawati ,Suwardi Annas, Saripuddin D, Muh. Yahya. 11. Penggunaan Model Explicit Instruction Untuk Meningkatkan Kemampuan Siswa Menulis Puisi Bebas Di Kelas V SD Nasional Sariputra Jambi Timur, Toni Sepriyadi. 12. Mathematical Resilience Mahasiswa Pada Mata Kuliah Struktur Aljabar I Menggunakan Pendekatan Explisit Instruction Integrasi Peer Instruction, Elsa Komala. 13. Pengaruh Model Explicit Instruction Dengan Metode Eksperimen Terhadap Kemampuan Mendeskripsikan Sifat-Sifat Cahaya Pada Siswa Kelas V SDN Bukur 3 Dan SDN Bukur 1 Nganjuk, Rara Junia Fransisca. 14. Penerapan Metode Explicit Instruction Berbantuan Media Buku Bergambar Dalam Meningkatkan Kemampuan Membaca Petunjuk Pemakaian, Ina Agustina, Ali Sudin2, Dede Tatang Sunarya. 15. Penerapan Model Explicit Instruction Dalam Pembelajaran Matematika Materi Bilangan Romawi Pada Siswa Kelas IV SD INPRES Kapasa Makassar, Agustan Syamsuddin Miftahul Jannah , Kristiawati.

Judul artikel yang pakai dalam penelitian ini merupakan judul-judul yang relavan yang pilih karena sudah memenuhi kriteria yang dicari penulis untuk meneliti adapun kriteria tersebuat adalah adanya pembahasan mengenai keterampilan berbicara dengan menggunakan model explicit instruction. artikel keterampilan berbicara yang berjumlah 7 artikel. Ke-7 artikel ini terdiri dari empat artikel ditulis oleh satu penulis, 1 artikel ditulis oleh dua orang penulis kemudian tiga artikel terdiri dari tiga penulis. Tahun terbit artikel keterampilan berbicara yaitu rentang tahun 2015-2020. Artikel yang terbit tahun 2015 berjumlah 1 artikel, artikel yang terbit tahun 2016 berjumlah 2 artikel, artikel yang terbit tahun 2019 berjumlah 1 artikel, artikel yang terbit tahun 2020 berjumlah 3 artikel. artikel - artikel keterampilan berbicara membahas tentang tujuan dari keterampilan berbicara.

Tujuan keterampilan berbicara terdiri dari 1-7 yang diamati dalam penelitian, tujuan keterampilan berbicara 1 yang diamati dalam proses pembelajaran berjumlah 1 artikel, tujuan keterampilan berbicara yang diamati dalam proses pembelajaran 6 artikel. selain itu, jumlah artikel keterampilan berbicara terdiri dari 5 - 14 halaman. Satu artikel terdiri dari 5 halaman, satu atrikel terdiri dari 8 halaman, dua artikel terdiri dari 9 halaman, satu artikel terdiri dari 10 halaman, satu artikel terdiri dari 12 halaman, dan satu artikel terdiri dari 14 halaman. Keterampilan berbicara terdiri dari 10 indikator yang terdapat pada teori yang diamati dalam penelitian, indikator 0 keterampilan berbicara dalam proses pembelajaran berjumlah 3 artikel, indikator 1 keterampilan berbicara dalam proses pembelajaran berjumlah 2 artikel, indikator 5 keterampilan berbicara dalam proses pembelajaran berjumlah 1 artikel, indikator 6 keterampilan berbicara dalam proses pembelajaran berjumlah 1 artikel. 
Analisis penulis mengenai artikel tentang keterampilan berbicara bahwa penulis artikel keterampilan berbicara terdiri dari 1 orang dan diterbitkan pada tahun 2020. Indikator keterampilan berbicara yang diamati dalam penelitian ini terdiri dari 6 indikator akan tetapi ada juga artikel yang tidak membahas tentang indikator keterampilan berbicara, karena setiap artikel tidak mengamati indikator keterampilan berbicara yang sama. Dan setiap artikel memiliki permasalahan yang berbeda-beda sehingga setiap penulis berusaha untuk lebih mengkrucutkan kepada permasalahan yang diamati dalam proses pembelajaran.

Dari ke-7 artikel yang sudah dianalisis, menurut penulis artikel terbaik mengenai keterampilan berbicara adalah nomor 5 yang ditulis oleh Vitta Kariani (2016). Ia menjelaskan 6 indikator keterampilan berbicara yang sesuai dengan teori, sehingga kita sebagai peneliti dapat mengetahui indikator-indikator yang termasuk kepada keterampilan berbicara. Selain menjelaskan indikator-indikator keterampilan berbicara ia juga menjelaskan tentang faktorfaktor yang menyebabakan rendahnya tingkat keterampilan berbicara pada siswa. Ini sangat diperlukan oleh pembaca agar mengetahui bagaimana cara meningkatkan keterampilan berbicara pada siswa sehingga tujuan pembelajaran dapat tercapai dengan maksimal.

Artikel Model Explicit Instruction terdiri dari 8 artikel dan diterbitkan dijurnal nasional pada tahun 2015-2020. Dari 8 artikel yang dianalisis, 3 artikel terdiri dari satu penulis, 1 artikel terdiri dari 2 penulis, 3 artikel terdiri dari 3 penulis, dan 1 artikel terdiri dari 4 penulis. Artikelartikel ini diterbitkan dijurnal nasional pada tahun 2015-2020, 3 artikel terbit pada tahun 2016, 2 artikel terbit pada tahun 2017, 1 artikel terbit pada tahun 2018, 2 artikel yang terbit tahun 2019.

Selain itu model explicit instruction terdiri dari langkah- langkah yang bertujuan memudahkan guru dalam menyampaikan materi kepada siswa, pada ke-2 artikel ini terdapat langkah- langkah model explicit instruction. Artikel dengan langkah- langkah explicit instruction terdiri dari 2 artikel. Selain itu, halaman artikel model explicit instruction terdiri dari 6-19 halaman. 1 Artikel terdiri dari 6 halaman. 2 Artikel terdiri dari 7 halaman, 2 artikel terdiri dari 8 halaman, 2 artikel terdiri dari 10 halaman, 1 artikel terdiri dari 19 halaman.

Menurut penulis artikel tentang model explicit instruction ditulis oleh 1-4 orang dan diterbitkan pada tahun 2016-2020 dijurnal nasional. Selain itu setiap artikel pada Model Explicit Instruction memiliki tahapan dan langkah-langkah berbeda-beda. Selain pada permasalahan yang berbeda- beda, langkah-langkah model explicit instruction dimodifikasi oleh setiap penulis untuk memudahkan masalah pada penelitiannya. artinya setiap model Explicit Instruction memiliki langkah-langkah yang berbeda-beda yang disesuaikan dengan materi, permasalahan dan situasi tempat penelitian. Artikel yang membahas langkah-langkah model explicit instruction berjumlah 1 artikel. Artikel yang membahas sintak terdapat 4 artikel. Dan 3 atrikel yang tidak membahasa langkah-langkah dan sintak dari model explicit instruction.

Apabila saya merujuk pada buku yang ditulis oleh Shoimin (2016) yang berjudul 68 model pembelajaran inovatif dalam kurikulum 2013, buku tersebut juga membahas tentang model pembelajaran explicit instruction. Setelah saya lakukan analisis kemudian saya bandingkan dengan artikel terbaik menurut pendapat saya, ternyata model explicit istruction memiliki langkah-langkah yang sama dengan artikel yang terbaik menurut saya.

Dari ke-8 artikel yang telah dianalisis, menurut penulis artikel terbaik berkaitan dengan model explicit instruction adalah nomor 9 yang ditulis oleh Rahmawati Utari Desak Putu Parmiti dan kawan-kawan (2016). Ia menjelaskan 5 langkah-langkah model explicit instruction .dalam penelitian Rahmawati Desak Putu Parmiti (2016) menggambarkan langkah-langkah yang lebih spesifik yang sesuai dengan teori. Dengan maksud menspesifikkan langkah-langkah model explicit instruction yang diamati dalam proses pembelajaran. Langkah-langkah yang mudah dipahami dan mampu disesuaikan dengan tempat penelitian. 


\section{SIMPULAN}

Kajian literatur tentang keterampilan berbicara dengan menggunakan model Explicit Instruction dapat disimpulkan bahawa dari 15 artikel yang dianalisis 46,6 \% tentang keterampilan berbicara, artikel membahas tentang model explicit instruction $53,3 \%$. dari 15 artikel yang membahas tentang keterampilan berbicara terdiri dari 7 artikel, dan 8 artikel yang membahas tentang model Explicit Instruction.

Artikel yang terbaik dari 7 artikel tentang keterampilan berbicara adalah hasil penelitian yang dilakukan oleh Vitta kariani (2016). Artikel yang terbaik dari 8 artikel tantang Model Explicit Instruction adalah hasil penelitian yang dilakukan oleh Rahmawati Utari Desak Putu Parmiti , dkk (2016).

\section{DAFTAR PUSTAKA}

Afiffudin. 2012. Metodologi Penelitian Kualitatif. Bandung: Pustaka Setia.

Agus Darmuki. Dkk. Jurnal Kredo Vol.2 No.2 2019. Peningkatan Keterampilan Berbicara Menggunakan Metode Kooperatif Tipe Jigsaw Pada Mahasiswa PSBI Tingkat I-B Ikip Pgri Bijinegoro.

Mufarizuddin, 2017 Jurnal BASICEDU Peningkatan Hasil Belajar IPS Dengan Menggunakan Model Inkuiri Siswa Kelas IV SD Negeri 016 Bangkinang Kota.

Mulyana,(2001). Ilmu Komunikasi: Suatu Pengantar. Bandung: Remaja Rosda Karya.

Trianto. 2009. Mendesain Model Pembelajaran Inovatif-Progresif. Jakarta: Kencana Prenada Media Group.

Vitta Kariani. Ejurnal Bahasantodea Vol.4 No.2 2016. Peningkatan Keterampilan Berbicara Melalui Model Pembelajaran Kooperatif Tipe Artikulasi Pada Siswa Kelas IV SD Inpres 3 Talise.

Witarsa, 2015 Jurnal Program Studi Pendidikan Guru PAUD STKIP Siliwangi Pengembangan Program Pelatihan Untuk Meningkatkan Kompetensi Guru Dalam Memfasilitasi Keterampilan Berfikir Kritis Anak Usia Dini. Bandung 